\title{
Wistar's export to Argentina
}

SIR-Argentinian scientists have recently been disturbed by an experiment involving both humans and domestic animals infected with a live recombinant vaccine. [An account of the experiment appeared in Nature $(324,202 ; 1986)$ after this letter was written.]

The experiment was carried out in an experimental farm of the Panamerican Health Organization of Azul, province of Buenos Aires, following a protocol designed by the Wistar Institute of Philadelphia; it was supervised by Dr J. Held (director of Centro Panamerico de Zoonosis, CEPANZO, PAHO), Ana Maria Diaz (head of the rabies unit), Elmo de la Vega (chief of pathology) and Luis Lazaro (chief of the Azul Field Station).

The experimental protocol was presented by Dr Roberto Weimann from the Wistar Institute, who flew to Buenos Aires immediately after the nature of the experiment became public, thanks to the action of a group of scientist from AADICYT, the Argentinian Association of Research Scientists. Soon after, the Argentinian Ministry of Health appointed a special committee of inquiry. After interviewing Weimann and visiting the premises of CEPANZO at Azul, the committee recommended the immediate interruption of the experiment, based on the following evidence:

(1) The experiment was started on 1 June 1986, without the permission, consent or notification of any Argentinian human or animal health authority.

(2) The effects and eventual risks of the inoculation of a rabies-vaccine recombinant virus in open-field cattle and its possible transmission to humans are completely unknown. The only reports in the current scientific literature deal with laboratory animals (mice and rabbits, Proc. natn. Acad. Sci. U.S.A. 81, 7194, 1984) and foxes kept in captivity (Nature $322,373 ; 1986)$. There is particular concern about a possible alteration in the tissue localization of the recombinant virus as in the case of the Moloney murine leukaemia virus-rabies recombinant (M.P. Kriegler and C. Perez, Scientific Report 84/85, Institute for Cancer Research, Fox Chase Cancer Center) that might produce long-term consequences difficult at present to assess.

(3) There were serious violations of ethical, ecological and safety rules:

- The inoculated animals were not kept in isolation, permitting the free access of other wild and domestic animals to the area, with the danger of spreading the new virus in an open ecosystem.

- No warning signs were placed at the experiment area.

- There were precise instructions that the same two animal handlers should milk each group of cows throughout the experiment.

- The four animal handlers were not vaccinated against smallpox before starting the experiment. The only sign of previous immunization considered by those responsible for the experiment was the presence of a scar compatible with vaccination.

- The four animal handlers were not under medical surveillance.

- Some of the milk from the inoculated cows was consumed by the animal handlers and their families without being pasteurized. The bulk of the milk was sent to the local market, and distributed to the community after pasteurization.

- The way in which this experiment was performed clearly infringes the World Health Organization's recommendations about experience involving recombiant DNA technology (Bethesda, 1984, Geneva, 1985).

We are not against the development of recombinant vaccine technology in view of its potential value for effective disease control. But we think that recombinant vaccines, like any other recombinant DNA project involving humans, must be developed in the light of international laws and recommendations, caring ethical and ecological consequences.

Moreover, we feel that our country has been illegally used as a test field for a kind of experiment that is not yet accepted in the countries where basic research on this vaccine had originated.

Pablo R. Grigera Centro de Virologia Animal (CEVAN), Serrano 665-1414 Capital Federal, Argentina

- This letter is signed by 134 Argentine scientists.

\section{Defensive deterrent}

SIR-At the time I was approached, I objected to the Cornell survey of National Academy members (Nature 324, 4; 1986) as to the feasibility and desirability of the Strategic Defense Initiative (SDI) even though I agree that no defensive system would be able, within the next 25 years, to provide effective population defence, even if the Soviets froze their arsenals at current levels. But as Reykjavik (which took place after the survey was completed) demonstrated, this is not the right question. Rather, we should be asking whether, if arms control leads to a mutually agreed reduction in the offensive threat to, say, a few hundred offensive missiles, can a defensive system be effective against this much lower threat? The answer to this question is probably yes; I would guess that many of my fellow academicians who denied the feasibility of a defensive system against the current threat would concede that defence is feasible against a lower offensive threat. That those responsible for the Cornell survey did not give the respondents this choice I consider to be an improperly restrictive view of the matter.

Indeed, the entire episode reflects a curious bias in the academic world against the so-called defensive-dominated world. A defence-dominated world in which peace is maintained by denial of aggressive intent is surely morally superior to the present offence-dominated world in which peace is maintained by threat of mutual genocide - provided the defencedominated world and the transition thereto can be adequately stable.

Rather than sanctifying the current offensive world as being the only one in which peace is maintained, academic peace studies groups ought to be examining in full seriousness the defensive world. Reykjavik gives us a glimmer of hope that the first step to a defensive transition deep reductions in offence - is not a willo'-the-wisp. How to stabilize such reduction by appropriate defensive deployment and how to redirect SDI towards this goal ought to be central elements in academics' peace agenda, much more than illconsidered, and I fear, politicallyinspired, attempts to discredit any movement toward a defence-dominated world.

Alvin M. WeINBERG

Instititute for Energy Analysis,

Oak Ridge Associated Universities,

PO Box 117, Oak Ridge,

Tennessee 37831-0117, USA

\section{South Africa}

SIR-Britain took 96 years to get full suffrage, in four stages, the last only 58 years ago. During that time, poverty (far greater than that in South Africa today) virtually disappeared, owing to the gradual increase in wealth brought about by entrepreneurs. South Africa needs more trade and contacts with other countries so that it can continue to raise the average standard of living.

The advanced countries demand that South Africa make really major social changes much more quickly than they did; at the same time they apply sanctions that cripple its power to do so. Such behaviour may be explained, but not excused, by the campaign against South Africa in the media, especially television, during the past year or so. The letter of J.A. Barnes (Nature 324, 104; 1986) rather dispels the hope that an academic would show more understanding.

Delgany,

J.A.D. EWART

Solesbridge Lane,

Chorleywood,

Rickmansworth,

Hertfordshire WD3 5SW, UK 